\title{
The Effects of Pesticides on Dictyostelium Cholinesterase, from Basic to Applied Research
}

\author{
Andrea Amaroli \\ University of Genoa, DIPTERIS, I-16132 Genova, \\ Italy
}

\section{Introduction}

Numerous organisms have been proposed as biotests in standardised laboratory procedures to evaluate contamination caused by pesticides. In this context, protozoa are regarded as a valuable assay to be exploited in laboratory investigations because of their fundamental features. Due to their nature as eukaryotic cells/organisms, protozoa exhibit a relatively simple organisation and a high degree of specialisation. As eukaryotic organisms, protozoa behave like animals, responding directly to environmental stimuli, but, as single-cells, they are more sensitive to environmental changes than the cells of higher organisms. Like microorganisms generally, protozoa multiply through short cell-cycles and this makes it possible to detect the effects of pesticides on large and genetically homogeneous cell populations and on their progeny as well. These peculiarities of protozoa are more interesting if we consider how the test on protozoa can assuage public opinion, more and more sensible to bioethical matters and meet the requests of both the ICCVAM and the ECVAM for compliance with the 3Rs strategy. Furthermore, it is important to highlight that the identification of molecules functionally related to neurotrasmission in protozoa (such as the GABAergic system in Paramecium and Dictyostelium, the nitrergic system in Paramecium and the cholinergic system in Paramecium, Dictyostelium and Euplotes, through which they can react to environmental stress, like the molecules of macroinvertebrate and vertebrate models) provides a new method for using protozoa in neurotoxicity tests and as ecological indicators in biomonitoring. This paper will focus on the inhibition of Dictyostelium ChE activity as a biomarker of exposure to neurotoxic pesticides and how this biomarker can be used in the field for the pre-chemical screening of estuarial zones. The area investigated was the western coast of Liguria, an area stretching from Genoa to the French border, whose economy is based on greenhouse market gardening, olive oil production and summer tourism. In this area, it is important to convince people of the need for continuous biomonitoring to maintain the balance between intensive farming and tourism on the one hand and environmental and public health on the other for sustainable development.

\section{Protozoa, a micro-organism model for modern environmental biomonitoring}

To assuage ever-increasing public concern over bioethical matters such as laboratory-animal suffering, the scientific community has tried to find alternative research models 
(Schechtman, 2002). This has been a centuries-long process, beginning in Great Britain in the early nineteenth century with the first bioethical law, "The Cruelty to Animals Act", as reported by Orlans (1993), which had the objective of controlling animal experimentation (Flecknell, 2002). However, it was only with the publication of the article of Russel \& Burch (1959), entitled "The Principles of Humane Experimental Technique", that it was clearly stated that in experimentation every effort must be made to ensure that animals do not suffer.

In this article the authors proposed the use of the 3Rs strategy:

Replace $=$ the use of animals must be replaced with alternative techniques or avoided altogether;

Reduce $=$ the number of animals involved must be reduced to an absolute minimum;

Refine $=$ the experimental parameters must be refined to make sure animals suffer as little as possible (Russell \& Burch, 1959).

Unfortunately, this ethical method has received scarce attention from the scientific community in the past and only recently has it obtained the interest of the Interagency Coordinating Commitee on the Validation of Alternative Methods (ICCVAM) and the European Centre for the Validation of Alternative Methods (ECVAM), due to proposals for new laws to regulate animal experimentation (Balls et al., 1995; Stokes \& Hill, 2000; Schechtman, 2002). The need to regulate animal experimentation is made more urgent if you consider the data reported by the EU system for the Registration, Evaluation and Authorisation of Chemicals (REACH), which lists about 3,000 new chemical substances, including many pesticides, that will have to be analysed over the next twelve years before being released on the market (Louekari et al., 2006), and which, according to the European Commission Joint Research Centre, will require between 2.1 and 3.9 million animals to complete all the necessary tests. Given the numbers involved, it is not surprising that interest in alternative experimental methods and the $3 \mathrm{Rs}$ has increased, even in the industrial sector, which must reduce the costs of experimentation by between 1,143 and 2,274 million euro to satisfy the criteria dictated by REACH (Grindon \& Combes, 2006; Grindon et al., 2006).

In recent years numerous organisms have been proposed as alternative vertebrate experimental models for the evaluation of toxicological risks from man-made compounds. In this context, the protozoa, unicellular eukayotic organisms that have long inhabited aquatic and terrestrial habitats and so developed adaptment strategies to survive environmental perturbations (Fenchel, 1987), can be considered excellent laboratory models (Apostol, 1973).

In fact, due to their nature as eukaryotic single cells/organisms, the protozoa exhibit a relatively simple organisation and a high degree of specialisation. As organisms, the protozoa respond directly to environmental stimuli like the metazoan, while, as single cells, which expose their receptors directly to the surrounding environment, they are more sensible to environmental modifications than the metazoa cells, which have developed complex apparatuses and structures that respond to environmental stimuli according to their diverse functions. Furthermore, as the ancestors of the metazoan, the experimental response of the protozoa can be correlated with those of the more developed organisms.

An advantage of using protozoa in toxicological studies is that their short cell cycles allow the analysis of the toxic effects of a contaminant on a conspicuous number of cells, genetically homogeneous populations and successive generations in a short time. In addition, the absence of a cellular sheath in the vegetative state allows the protozoa to 
respond to the stimulus more rapidly than bacteria and yeasts. Furthermore, they can be cultured in the laboratory under conditions very similar to those in nature, making their response more reliable than that of animal-cell cultures cultured in artificial conditions (Delmonte Corrado et al., 2006).

Finally, it is important to emphasise how in protozoa, the identification of molecules responsible for neurotransmission in metazoan, such as those belonging to the GABAergic system in Paramecium primaurelia (Ramoino et al., 2010) and Dictyostelium discoideum (Anjard \& Loomis 2006), to the nitergic system in Paramecium primaurelia (Amaroli et al., 2010), and to the cholinergic system in Paramecium primaurelia, Dictyostelium discoideum, Euplotes crassus (Delmonte Corrado et al.,1999; Amaroli et al. 2003; Trielli et al., 2007), with characteristics similar to those of the vertebrates, has opened the way to their use in neurotoxicological studies. The genomal sequencing of several protozoa (Dessen et al. 2001; Turkewitz et al., 2002; Eichinger et al., 2005), has demonstrated that they have conserved gene sequences compared to human genome and this has stimulated the interest of the scientific community in their use in field studies on human health, as in the case of Dictyostelium discoideum included in the eight alternative models to be used instead of vertebrates in human health studies in the USA (Williams et al., 2006).

The characteristics listed above make the protozoa excellent biological assay tools, combining the reliability of in vivo results with the practicality of in vitro, to be used in toxicological studies and wider studies of the effects of environmental perturbations (Persoone \& Dive, 1978; Denis et al., 1992; Ricci, 1995; Sauvant et al., 1999; Miyoshi et al., 2003; Delmonte Corrado et al., 2006;).

\section{Basic research into the effects of pesticides on Dictyostelium cholinesterase}

The cholinergic system has been extensively studied as the cholinergic molecules play the role of specialised transmitters of nervous signals at myoneural junctions, regulating the intercellular messages by varying the ionic content of the cytoplasm.

The cholinergic transmitter system includes the signal molecule acetylcholine (ACh), synthesised by the enzyme choline acetyltransferase (ChAT, E.C. 2.3.1.6), which catalyses the acetylation of choline with acetyl coenzyme-A (Nachmansohn \& Machado, 1943), and both classes of ACh receptors, the nicotine-sensitive ones (Stroud et al., 1990) and the muscarine-sensitive ones (Birdsall et al., 1978), which play different roles in excitable cells, even though activated by the same signal molecule. The activity of the ACh lytic enzyme acetyl-cholinesterase (AChE) modulates the reception function by hydrolysing the receptorbound ACh on the surface of target cells. More generally, the ChEs refer to enzymes able to hydrolyse $\mathrm{ACh}$ and other choline esters into their respective components, choline and acetate, or butyrate or propionate (Stedman \& Easson, 1932).

Depending on the species, different ChEs have been detected and characterised on the basis of their catalytic properties, depending both on the substrate hydrolysed by their activity and on their sensitivity to specific inhibitors (Mendel \& Rudney, 1943; Talesa et al., 1990).

AChE activity, also referred to as "true" AChE (E.C. 3.1.1.7) and present in higher organisms with specialised synapses (Massoulié et al., 1993), hydrolyses either ACh with high affinity and the substrate acetyl- $\beta$-methyl thiocholine iodide (AcTChI). This enzyme activity is inhibited by eserine, a carbamate compound, and more specifically, by BW 284c51, a phenol 
ester. Among the other choline esters are butyrylcholinesterase (BChE, E.C. 3.1.1.8) and propionyl-cholinesterase (PrChE), also referred to as "pseudocholinesterases", that preferentially hydrolyse the substrates butyryl thiocholine iodide (BTChI) and propionyl thiocholine iodide (PrChI) respectively (Talesa et al., 1990). Both BChE and PrChE enzyme activities are inhibited by eserine and, more specifically, by iso-OMPA, a phosphoramide compound.

As reported in Section 2, there is some information on the presence and functional role of the molecules related to the cholinergic system in protozoa. In particular, in this review, attention is focused on the ChE of Dictyostelium discoideum single-cell amoebae. This protozoa, often referred to as "slime mould", exhibits a very simple organisation with a very complex developmental cycle. The life cycle of D. discoideum (Fig. 2) starts with the multiplication phase by binary fission of single-cell amoebae feeding on bacteria. Depletion of the food source triggers the aggregation and differentiation phase. The amoebae aggregate and migrate towards an extracellular cyclic AMP signalling source by chemotaxis, giving rise to the first multicellular stage, which undergoes the process of culmination leading to the formation of the fruiting body (Loomis, 1975; Escalante \& Vicente 2000). In D. discoideum, we citochemically and spectrophotochemically detected ChE activities able to cleave the substrate PrChI with high affinity and the substrate AcTChI, with less affinity (Falugi et al., 2002). The non-denaturing electrophoresis pattern showed that the PrChI substrate was hydrolysed by a single enzyme activity, while the AcTChI susbstrate was hydrolysed by two enzyme activities, one migrating like the $260-\mathrm{kDa}$ molecular form of Electrophorus electricus AChE and the other corresponding to the molecular form revealed by the PrTChI substrate (Falugi et al., 2002). To characterise the PrChE, we spectrophotometrically evaluated the effects of $\mathrm{pH}$, temperature variations and specific inhibitors. It is important to underline that a $10^{-5} \mathrm{M}$ iso-OMPA concentration completely blocked the PrChE activity (Delmonte Corrado et al., 2005). Moreover, the full genome sequencing of Dictyostelium discoideum enabled us to detect a putative sequence of a protein, that showed a similarity to a pseudocholinesterase of the vertebrates.

The inhibition of ChE activity was one of the first validated environmental biomarkers and it has been employed widely for over thirty years as a specific biomarker of exposure to pesticides, such as the organophosphate (OP) and carbamate (CA) compounds used world wide for agriculture pest control (Kennedy, 1991; Hassal, 1990). These compounds, less persistent in the environment but more toxic than the organochlorine pesticides, are anticholinesterase agents that have been designed to be effective inhibitors of ChE activity. The organophosphate pesticides are esters or thiols derived from phosphoric, phosphonic, phosphinic or phosphoramidic acid. Their basic chemical structure is shown in Fig. 1A. generally, R1 and R2 are aryl or alkyl groups, while $\mathrm{X}$ refers to a wide range of groups: halogen, aliphatic, aromatic and heterocyclic (Kuhr \& Dorough, 1976). The OP pesticides destroy ChE activity by phosphorylating a specific serine residue within the ChE catalytic centre and under this condition the enzyme is unable to hydrolyse the choline esters (Kennedy, 1991; Gallo \& Lawryk, 1991). The CA pesticides are derivates of carbamic acid. Their basic chemical structure is shown in Fig. 1B. Generally R1 and R2 are organic radicals or a metal. Carbamates have insecticide properties when R2 is an H and R1 a methyl; herbicidal properties when R1 is an aromatic group; fungicidal properties when R1 is a component of benzimidazole. The CAs, like the OPs, act on the serine within the ChE catalytic centre through a carbamylation reaction. However, unlike the OPs, the inhibition of ChE activity by CAs is a reversible process (Kuhr \& Dorough, 1976; Baron, 1991). 
A

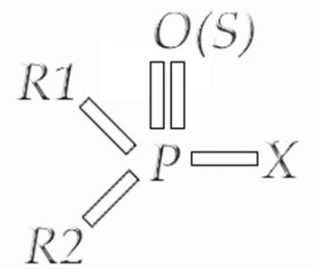

B

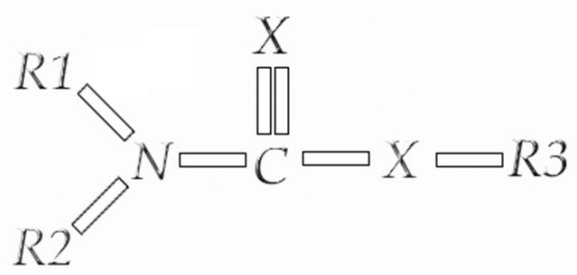

Fig. 1. Chemical structure of organophosphate (A) and carbamate (B) compounds.

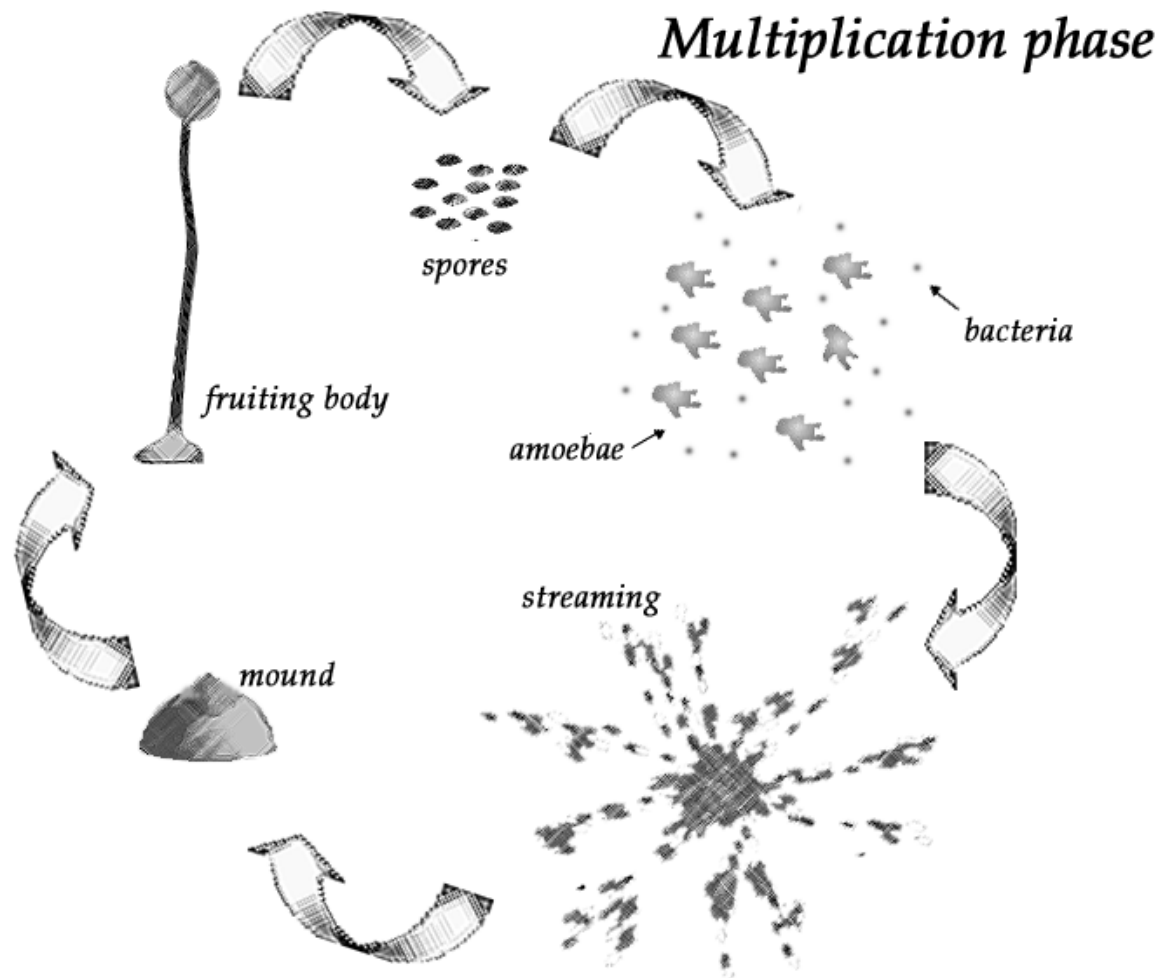

\section{Aggregation and differetiation phase}

Fig. 2. A simplified scheme of the developmental cycle of Dictyostelium discoideum. The life cycle start from the multiplication phase, during which single-cell amoebae feed bacteria, grow, and reproduce by binary fission. The next phase starts from the depletion of food supply that triggers aggregation of the amoebae in stream to form multicellular aggregate, the mound. The final phase culminates in the development of the fruiting body, containing the apical spore able to reproduce under suitable environmental conditions, and the stalk cells unable to multiply. 
To evaluate the possibility of exploiting the PrChE activity detected in D. discoideum as a specific biomarker of exposure to neurotoxic pesticides, we spectrophotometrically (Ellman et al., 1961) tested the sensitivity of this enzyme to OPs and CAs. The OPs employed were diazinon and cidial, which caused an inhibition of $67 \%$ and $52 \%$ respectively at a concentration of $10^{-6} \mathrm{M}$, whereas the CAs were carbaryl and pirimicarb, which caused an inhibition of $63 \%$ and $61 \%$ at the same concentration as the OPs (Falugi et al., 2002).

In addition, a dose-dependent inhibition of PrChE activity was found for diazinon concentrations ranging from $10^{-7} \mathrm{M}$ to $10^{-3} \mathrm{M}$. The identification of ChE activity, sensitive to exposure to OP and CA pesticides, in D. discoideum can avoid the interference of several stress factors in testing. In fact, several non-contaminant factors, such as type of tissue, species, genetic variation, age, sex, circadian and seasonal rhythms, reproductive state, and endocrine regulation can affect ChE activity, when invertebrates and vertebrates are exploited as test organisms for detecting the presence of pesticides (Rettner \& Fairbrother, 1991). On the contrary, these interference factors are excluded by the use of $D$. discoideum as the asexual reproduction of this unicellular organism gives rise to phenotypically and genotypically homogeneous cell lines. Furthermore, the stress factors that can interfere with D. discoideum PrChE activity are linked to the nutritional and physiological state of the culture and the culturing temperature and are eliminated by the standard conditions under which they are cultured.

\section{Applied research into the effects of pesticides on Dictyostelium cholinesterase}

Considering the results presented in the preceding section, we have examined the possibility of using the PrChE of D. discoideum as a biomarker for the pre-chemical screening of estuarial environments subject to pesticide pollution.

New Italian (D. L. n. 152/1999 and D. L. n. 258/2000) and European (Direttive CE 2000/60), regulations give particular attention to the quality of water and sediment, not only for their chemico-physical characteristics but also for their biocenotic content. In fact, the European Union is particularly interested in promoting chemico-physical and biological monitoring programmes for evaluating the health of the aquatic environment (Sandulli, 2004).

It has been noted how pollutants dispersed in the environment often finish, more or less rapidly, in the aquatic environment, where they can be absorbed by suspended particulate matter and then accumulated in the sediments. Therefore, the sedimentary deposits in contiguous marine and continental zones represent filters and storage for pollutants, constituting important sources of contamination for organisms (Geyer et al., 1984; Fulton \& Key, 2001; Bolton-Warberg et al., 2007; Moserrat et al., 2007). These coastal, estuarial and wet zones are particularly noted for their great biodiversity and are very important biotopes for the reproduction of numerous animal and vegetal species. Furthermore, pollution in these zones can have repercussions for the health of the human populations using their resources (McCauley et al., 2000; Pal et al., 2010; Azizullah et al., 2011). In fact, it has been noted that the residues of these substances act not only on the cholinergic systems of the pest invertebrates inhabiting these zones but also on the human cholinergic system and other enzymes such as the aliesterases, lipases, trypsin, chymotrypsin, succinoxidase, ascorbic acid oxidase, dehydrogenase, sulfhydryl enzymes (Gallo \& Lawryk, 1991). In a review, Gilden et al. (2010) noted that many articles described the toxic and epidemiological effects of exposure to pesticides, and particularly their effect on infant development. Furthermore, it has been reported that exposure to pesticides can be an important risk factor in the 
development of infant leukemia and it is necessary to protect the mother during pregnancy (Van Maele-Fabry et al., 2011). Numerous observations have emphasised the higher risk of people exposed to pesticides developing neurodegenerative diseases such as Parkinson's Disease (Weisskopf et al., 2010), and the relationship between exposure to pesticides and the development of tumors (Gold et al., 2001; Weichenthal el al., 2010).

Our study encompassed a stretch of the Ligurian coast between Genoa and the French border, whose economy is based largely on summer tourism and intensive market gardening in the areas between urban and tourist settlements. In fact, specialist fruit vegetable and flower producers, in close competition with northern European producers and, for some years, with those of South East Asia, have tended to rely increasingly on pesticides. The data is in line with that of the rest of the world and emphasised by The Worldwatch Institute (2006), according to which the consumption of pesticides has increased exponentially in recent decades, from $0.49 \mathrm{~kg} / \mathrm{ha}$ in 1961 to $2 \mathrm{~kg} / \mathrm{ha}$ in 2004 , with the consequences that these substances are now found in many foods (Akland et al., 2000).

It is, therefore, obvious that continuous environmental biomonitoring is necessary in this area to reach sustainable development, to balance agriculture and tourism and to protect the environment and the health of the inhabitants and visitors.

Our samples were taken from the Argentina Torrent in the Province of Imperia and the Centa Torrent in the Province of Savona, both critical areas subject to particular anthropic pressure, and the Arresta Torrent in the Province of Genoa as control area, as it has hardly been touched by anthropic development.

The Centa and Argentina torrents lie in areas of intensive agriculture, mainly specialising in olive oil production and growing flowers and plants, and there is a notable increase in the population at nearby seaside resorts in summer. Differently, the Arresta Torrent, lying on the border between the provinces of Genoa and Savona, flows through the Parco del Beigua natural area and geopark, and only near its mouth flows through scarcely inhabited and cultivated land.

The monitoring programme for the three torrents was based on the location of their cultivation and the characteristics of each watercourse (accessibility of the stream bed, granulometry of the sediment). In the case of the Argentina Torrent, two sites were studied, $100 \mathrm{~m}$ and $400 \mathrm{~m}$ from the swash zone, for the Centa, two sites $50 \mathrm{~m}$ and $400 \mathrm{~m}$ from the swash zone, and for the Arresta two sites $50 \mathrm{~m}$ and $200 \mathrm{~m}$ from the swash zone.

Samples of sediments and surface water were collected from each site. The sampling was performed monthly over the period 2007-10, taking meteorological and marine conditions into consideration. The samples were buffered at $\mathrm{pH} 8.0$ and the salinity determined before spectrophotometric analysis following Ellman et al. (1961).

The amoebae of $D$. discoideum exposed to water (data not shown) and elutriated sediment (Fig. 3) samples from the Arresta Torrent over the period 2007-10 did not show PrChE activity significantly different $(\mathrm{p}>0.05)$ from the control (commercial mineral water).

The amoebae of $D$. discoideum exposed to surface water from the Argentina Torrent did not demonstrate alterations in PrChE activity $(p>0.05)$ (data not shown). The situation was different for the amoebae exposed to samples of elutriated sediment from the Argentina Torrent, where the amoebae exposed to the sediment from the site $400 \mathrm{~m}$ from the swash zone had significantly increased PrChE activity $(\mathrm{p}<0.05)$ in November 2007 (Fig. 4A), November and December 2008 (Fig. 4B) and November and December 2009 (Fig. 4C). An analogous situation $(\mathrm{p}<0.05)$ was observed for the amoebae exposed to the elutriated sediment from the site $100 \mathrm{~m}$ from the swash zone in December 2007 (Fig. 4E) and December 2008 (Fig. 4F) 

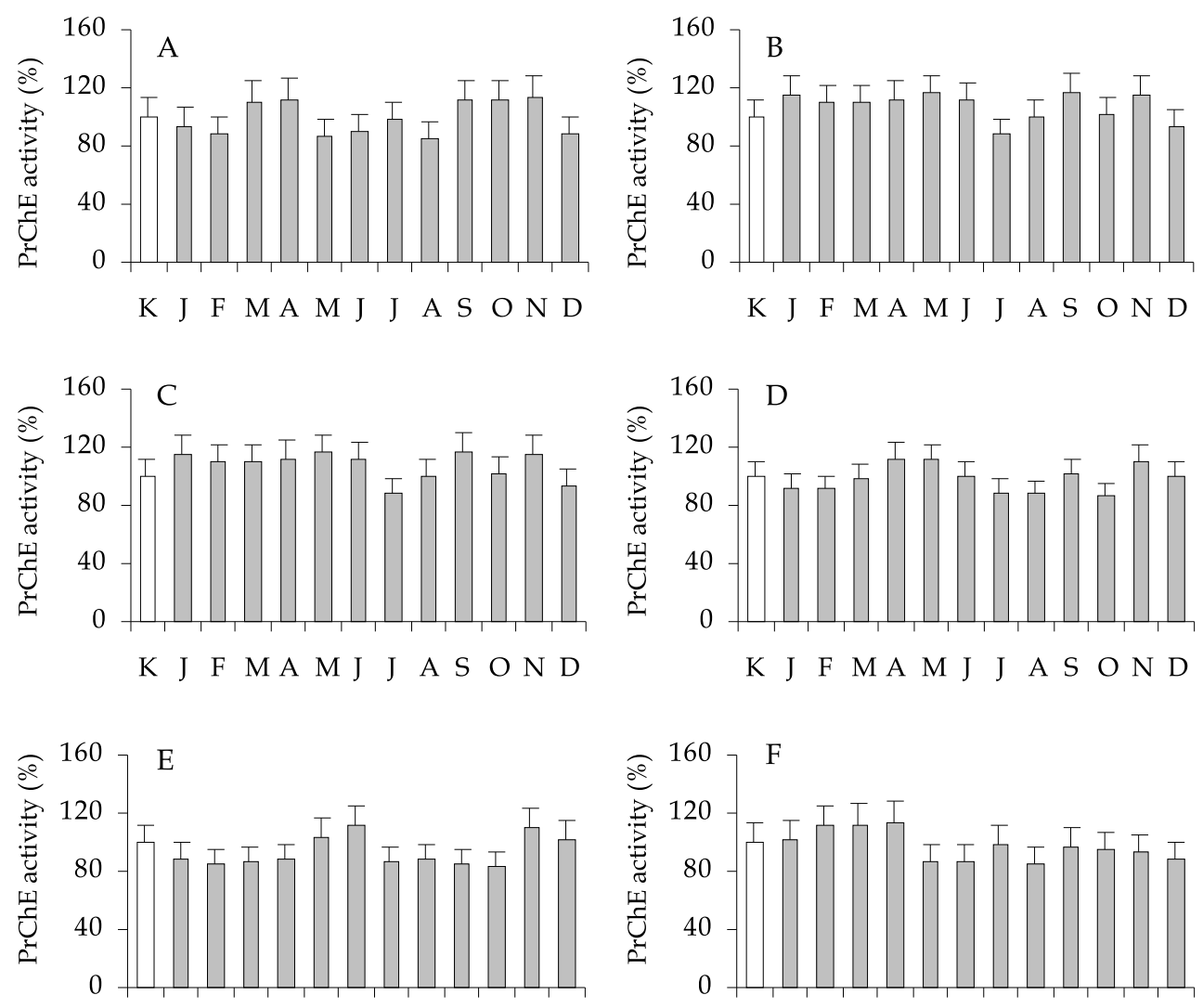

K J F M A M J J A S O N D

K J F M A M J J A S O N D
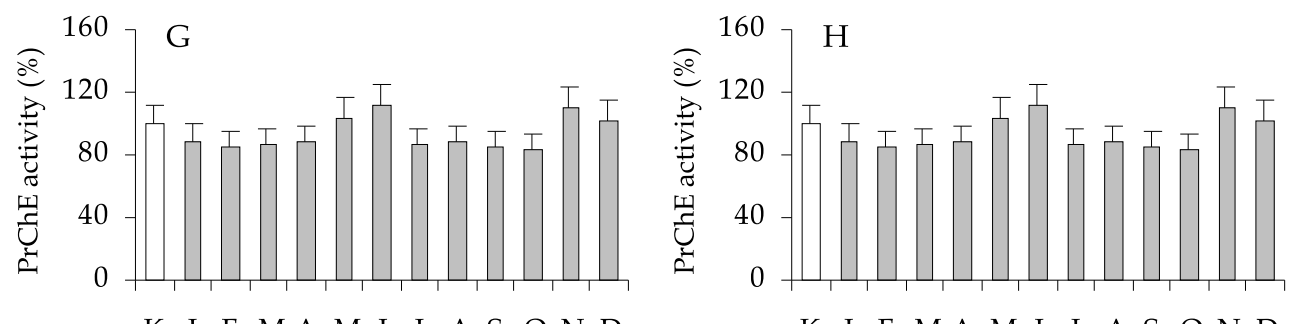

Fig. 3. PrChE activity in D. discoideum, measured after exposure to elutriated sediments from the Arresta Torrent. Samples collected $200 \mathrm{~m}$ from the swash zone in 2007 (A), 2008 (B), 2009 (C), and 2010 (D). Samples collected $50 \mathrm{~m}$ from the swash zone in 2007 (E), 2008 (F), 2009 (G), and $2010(\mathrm{H})$. Sampling months shown along the x-axis. The black columns indicate significant differences $(\mathrm{p}<0.05)$ from the control (commercial mineral water) $(\mathrm{K})$. 

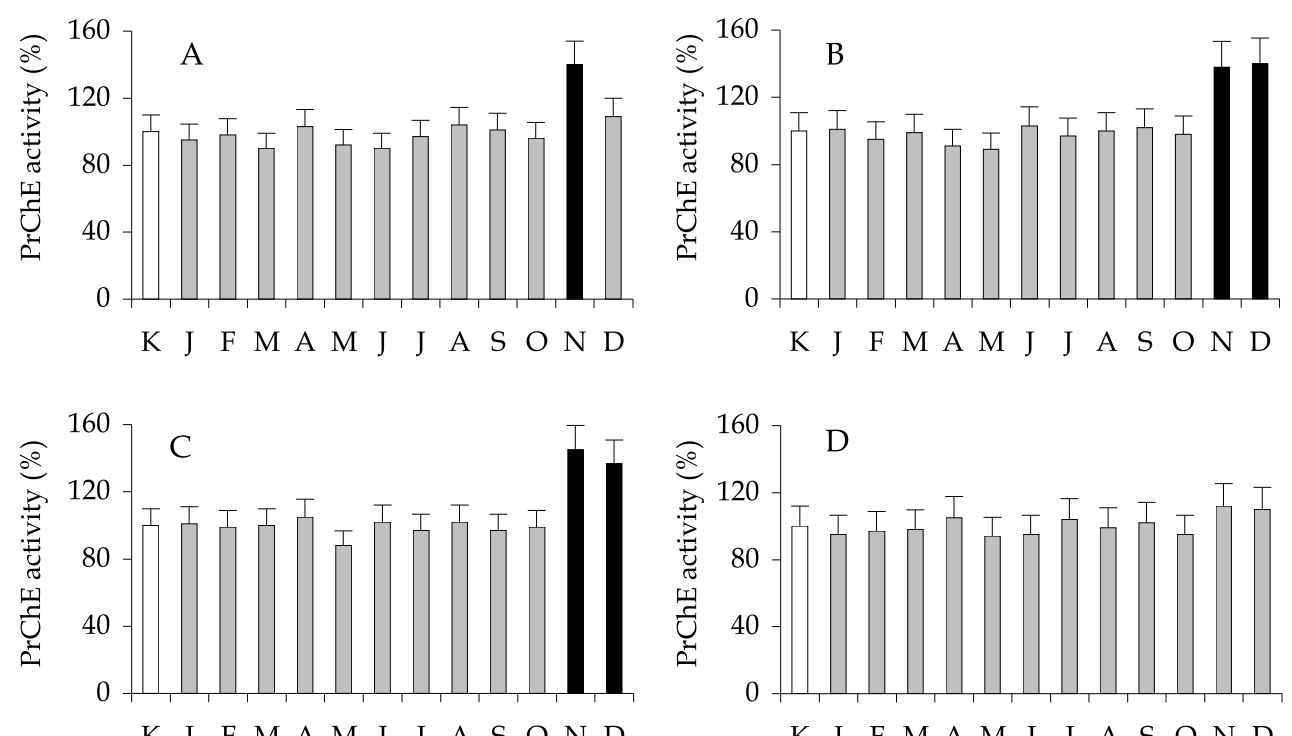

K J

K J
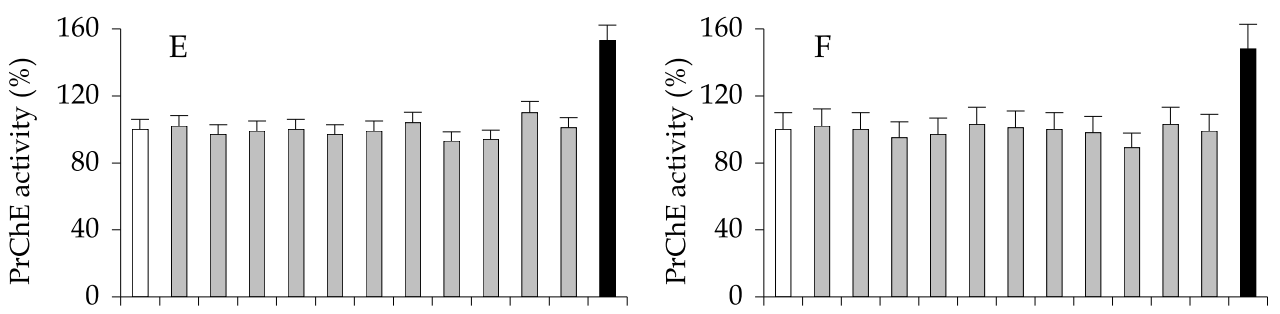

K J F M A M J J A S O N D

K J F
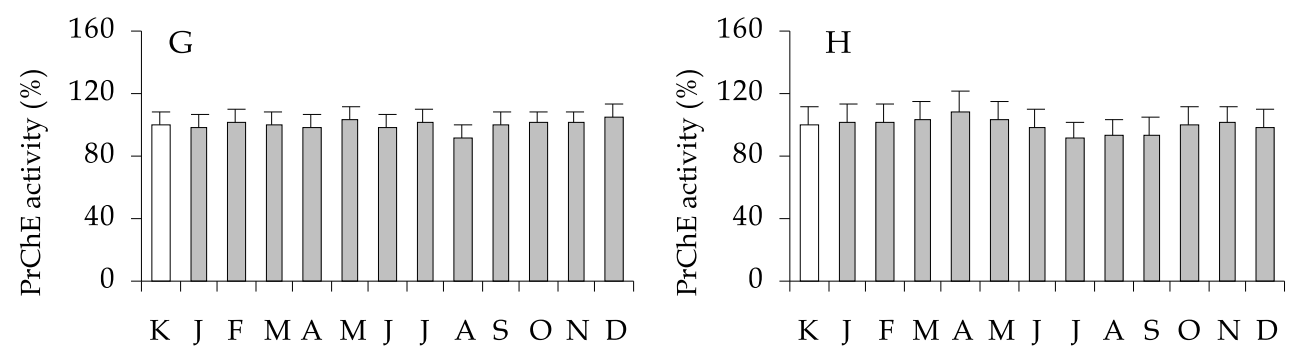

K J F M A M J J A S O N D

Fig. 4. PrChE activity in $D$. discoideum, measured after exposure to elutriated sediments from the Argentina Torrent. Samples collected $400 \mathrm{~m}$ from the swash zone in 2007 (A), 2008 (B), 2009 (C), and 2010 (D). Samples taken $100 \mathrm{~m}$ from the swash zone in 2007 (E), 2008 (F), 2009 $(\mathrm{G})$, and $2010(\mathrm{H})$. Sampling months shown along the $\mathrm{x}$-axis. The black columns indicate significant differences $(\mathrm{p}<0.05)$ from the control (commercial mineral water) $(\mathrm{K})$. 

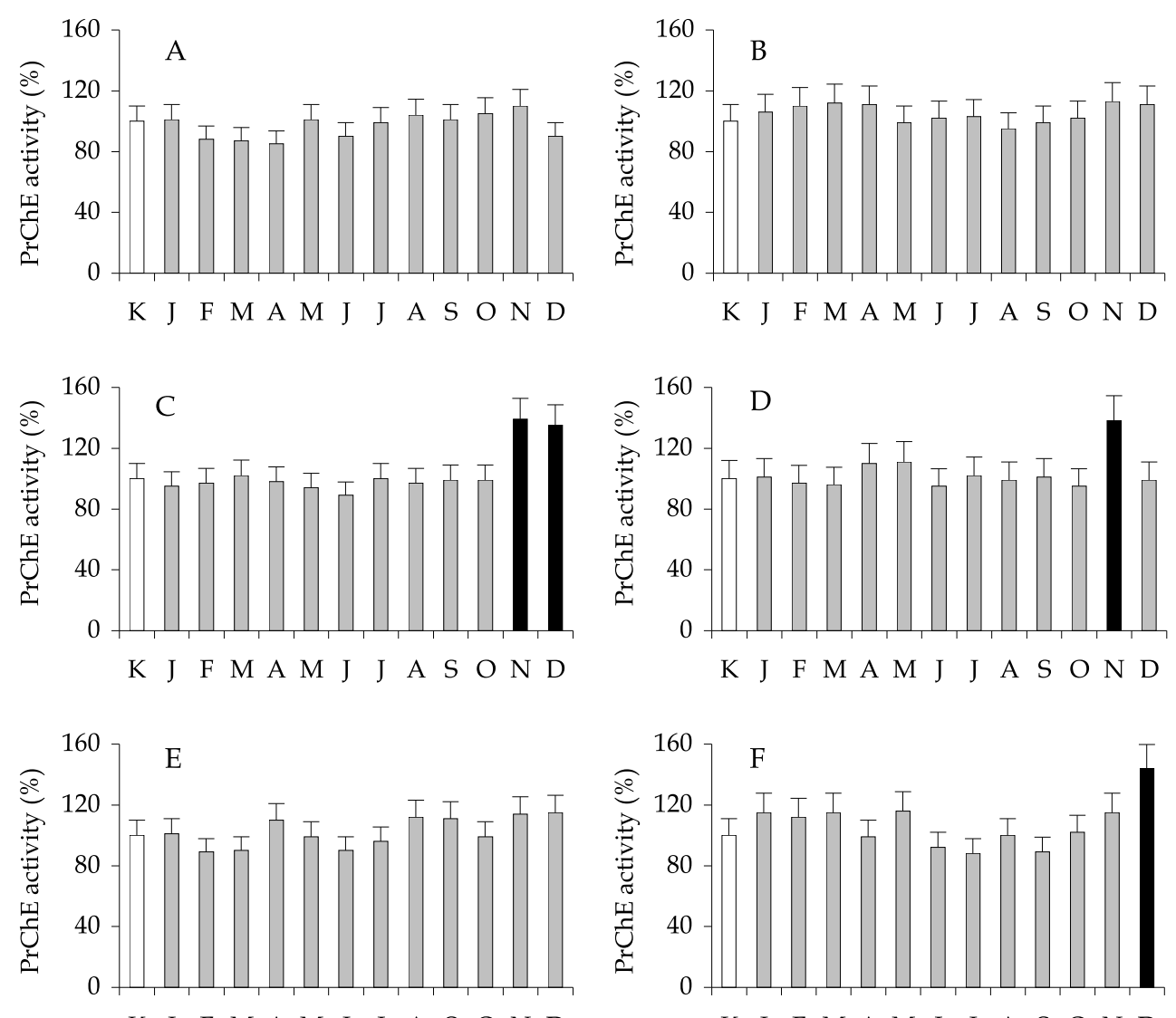

K J F M A M J J A S O N D

K J F M A M J J A S O N D
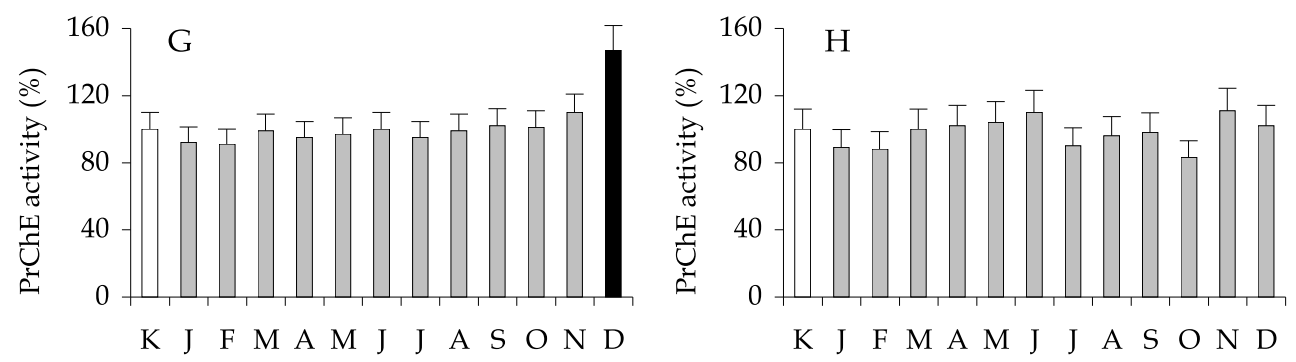

Fig. 5. PrChE activity in D. discoideum, measured after exposure to elutriated sediments from the Centa Torrent. Samples collected $400 \mathrm{~m}$ from the swash zone in 2007 (A), 2008 (B), 2009 (C), and 2010 (D). Samples taken $50 \mathrm{~m}$ from the swash zone in 2007 (E), 2008 (F), 2009 (G), and $2010(\mathrm{H})$. Sampling months shown along the x-axis. The black columns indicate significant differences $(\mathrm{p}<0.05)$ from the control (commercial mineral water) $(\mathrm{K})$. 
The amoebae of $D$. discoideum exposed to surface water from the Centa torrent did not demonstrate alterations in PrChE activity ( $p>0.05$ ) (data not shown), nor did those exposed to the elutriated sediments from the site $400 \mathrm{~m}$ from the swash zone in 2007 and 2008 (Fig. 5A, Fig. 5B) and the station $50 \mathrm{~m}$ from the swash zone in 2007 and 2010 (Fig. 5E, Fig. 5H). Instead, the amoebae exposed to the elutriated sediments from the site $400 \mathrm{~m}$ from the swash zone showed a significant increase $(\mathrm{p}<0.05)$ in PrChE activity in November and December 2009 (Fig. 5C) and November 2010 (Fig. 5D), as did those exposed to the sediments from the site $50 \mathrm{~m}$ from the swash zone in December 2008 (Fig. 5F) and December 2009 (Fig. 5G).

These increases in the PrChE activity of the amoebae of $D$. discoideum exposed to sediments from the estuarial zones of the Centa and Argentina Torrents indicates recurrent environmental stress in this area in the autumn-winter period. This result is more evident when compared to the situation of the Arresta Torrent, where no water or sediment sample induced a significant increase in PrChE activity in the exposed cells. Finally, the laboratory analyses exclude the possibility that the results are "artefacts" due to variations in the $\mathrm{pH}$ or salinity of the samples.

\section{Conclusion}

In conclusion, it is important highlight as, in vitro analysis, parallel studies have shown how some heavy metals and non-OP and -CA pesticides can induce a significant increase in the PrChE activity of exposed D. discoideum amoebae (Delmonte Corrado et al., 2006), so, it is possible to assume the presence of these substances in the sediments of Argentina Torrent and Centa Torrent. Analyses of the sediments of the zones we sampled have revealed the presence of pyrethroid pesticides in the autumn-winter period. These pesticides are able to induce a significant increase in cholinesterase as shown by studies on bees (Badiou \& Belzunces, 2008). The pyrethroid pesticides can enter the watercourses and then the estuarial sediments as a result of the abundant rain that falls in this period and floods the land dedicated to olive production treated with such pesticides in the fight against the olive fruit fly and other insects (Ruano et al., 2010), or the runoff from olive groves, which various studies have revealed contains high levels of pesticides (Karaouzas et al., 2010).

In conclusion, $D$. discoideum cholinesterase activity is a sensitive and reliable biomarker of the presence of pesticides in the sediments of watercourses subject to heavy anthropic pressure. A characteristic of great importance if we consider that this enzymatic activity occurs in a protozoa that responds to the conditions proposed by the 3Rs strategy and can assuage increasing international public concern over bioethical matters.

\section{Acknowledgment}

I am grateful to Prof. Maria Giovanna Chessa and Prof Carla Falugi, for their scientific support of my research in the fields of protozoa and cholinergic system, and for the critical reading of this manuscript.

\section{References}

Akland, GG.; Pellizzari, ED.; Hu, Y.; Roberds, M.; Rohrer, CA.; Leckie, JO. \& Berry, MR. (2000). Factors influencing total dietary exposures of young children. Journal of 
Exposure Analysis and Environmental Epidemiology, Vol.10, pp. 710-722, ISSN 10534245 .

Amaroli, A.; Gallus, L.; Passalacqua, M.; Falugi, C.; Viarengo, A. \& Delmonte Corrado, MU. (2003). Detection of cholinesterase activities and acetylcholine receptors during the developmental cycle of Dictyostelium discoideum. European Journal of Protistology, Vol.39, pp. 213-222, ISSN 0932-4739.

Amaroli, A.; Trielli, F.; Sifredi F.; Chessa, MG. \& Delmonte Corrado, MU. (2010). Nitric oxide production inhibited by xenobiotic compounds in the protozoan Paramecium primaurelia. Ecological Indicators, Vol.10, No.2, pp. 212-216, ISSN 1470160x.

Anjard, C. \& Loomis, WF. (2006). GABA induces terminal differentiation of Dictyostelium through a GABAB receptor. Development, Vol.133, No.11, pp. 2253-2261, ISSN 10116370 .

Apostol, S. (1973). A bioassay of toxicity using protozoa in the study of aquatic environment pollution and its prevention. Environmental Research, Vol.6, No.4, pp. 365-72, ISSN 0013-9351.

Azizullah, A.; Khattak, MN.; Richter, P. \& Häder, DP. (2011). Water pollution in Pakistan and its impact on public health--a review. Environment International, Vol.37, pp. 479497, ISSN 0160-4120.

Badiou, A. \& Belzunces, LP. (2008). Is acetylcholinesterase a pertinent biomarker to detect exposure of pyrethroids? A study case with deltamethrin. Chemico-Biological Interactions, Vol.175, pp. 406-409, ISSN 0009-2797.

Balls, M.; Goldberg, AM.; Fentem, JH.; Broadhead, CL.; Burch, RL.; Festing, MF.; Frazier, JM.; Hendriksen, CF.; Jennings, M.; van der Kamp, MD.; Morton, DB.; Rowan, AN.; Russell, C.; Russell, WM.; Spielmann, H.; Stephens, ML.; Stokes, WS.; Straughan, DW.; Yager, JD.; Zurlo, J. \& van Zutphen, BF. (1995). The three Rs: the way forward: the report and recommendations of ECVAM Workshop 11. ATLA Alternatives to Laboratory Animals, Vol.23, pp. 838-866, ISSN 02611929.

Baron, RL. (1991). Carbamate insecticides, In: Handbook of Pesticide Toxicology, JH. Wayland, RL. Edward, (Eds), 1125-1171, ISBN 978-0123341600, San Diego, USA.

Birdsall, NJ.; Burgen, AS. \& Hulme, EC. (1978). The binding of agonists to brain muscarinic receptors. Molecular Pharmacology, Vol.14, No.5, pp. 723-736, ISSN 0026-895X.

Bolton-Warberg, M.; Coen, LD. \& Weinstein, JE. (2007). Acute toxicity and acetylcholinesterase inhibition in grass shrimp (Palaemonetes pugio) and oysters (Crassostrea virginica) exposed to the organophosphate dichlorvos: laboratory and field studies. Archives of Environmental Contamination and Toxicology, Vol.52, pp. 207216, ISSN 0090-4341.

Delmonte Corrado, MU.; Amaroli, A.; Trielli, F. \& Falugi, C. (2006). Cholinesterase enzyme activity in protists and environmental biomonitoring. Current Trends in Microbiology, Vol.2, pp. 123-136, ISSN 0972-7736.

Delmonte Corrado, MU.; Politi, H.; Trielli, F.; Angelini, C. \& Falugi C. (1999). Evidence for the presence of a mammalian-like cholinesterase in Paramecium primaurelia (Protista, Ciliophora) developmental cycle. Journal of Experimental Zoology, Vol.283, No.1, pp. 102-105.

Delmonte Corrado, MU.; Trielli, F.; Amaroli, A.; Ognibene, M. \& Falugi, C. (2005). Protists ad Tools for Environmental Biomonitoring: Importance of Cholinesterase Enzyme 
Activities, In: Water Pollution - New Research. AR. Burk (Ed), 181-200, ISBN 1-59454393-3, New York, USA.

Denis, H.; Gilron, L. \& Gilron, GL. (1992). A brief review of approaches using ciliated protists to assess aquatic ecosystem health. Journal of Aquatic Ecosystem Stress and Recovery, Vol.1, No.4, pp. 263-270, ISSN 1386-1980.

Dessen, P.; Zagulski, M.; Gromadka R.; Plattner, H.; Kissmehl, R.; Meyer E.; Bétermier, M.; Schultz, JE.; Linder, JU.; Pearlman, RE.; Kung, C.; Forney, J.; Satir, BH.; Van Houten, JL.; Keller, AM.; Froissard, M.; Sperling, L. \& Cohen, J. (2001). Paramecium genome survey: a pilot project. Trends in Genetics, Vol.17, pp. 306-308, ISSN 01689525.

Eichinger, L., Pachebat, JA., Glöckner, G., Rajandream, MA., Sucgang, R., Berriman, M., Song, J., Olsen, R., Szafranski, K., Xu, Q., et al. (2005). The genome of the social amoeba Dictyostelium discoideum. Nature, Vol.435, pp. 43-57, ISSN 0028-0836.

Ellman, GL.; Courtney, KD.; Andreis, V. \& Feather-Stone, RM. (1961). A new and rapid colorimetric determination of acetylcholinesterase activity. Biochemical Pharmacology, Vol.7, pp. 88-95, ISSN 0006-2952.

Escalante, R. \& Vicente, JJ. (2000). Dictyostelium discoideum: a model system for differentiation and patterning. The International Journal of Developmental Biology, Vol.44, No.8, pp. 819-835, ISSN 0214-6282.

Falugi, C.; Amaroli, A.; Evangelisti, V.; Viarengo, A. \& Corrado, MU. (2002). Cholinesterase activity and effects of its inhibition by neurotoxic drugs in Dictyostelium discoideum. Chemosphere, Vol.48, No.4, pp. 407-14, ISSN 0045-6535.

Fenchel, T. (1987). Ecology of Protozoa: The Biology of Free-Living Phagotrophic Protists. Madison/Springer-Verlag, ISBN 978-3540169604, Berlin, Germany.

Flecknell, P. (2002). Replacement, Reduction and Refinement. ALTEX, Vol.19, No.2, pp. 7378, ISSN 0946-7785.

Fulton, MH. \& Key, PB. (2001). Acetylcholinesterase inhibition in estuarine fish and invertebrates as an indicator of organophosphorus insecticide exposure and effects. Environmental Toxicology \& Chemistry, Vol.20, pp. 37-45, ISSN 0730-7268.

Gallo, MA. \& Lawryk, NJ. (1991). Organic Phosphorous Pesticides, In: Handbook of Pesticide Toxicology, JH. Wayland, RL. Edward, (Eds), 917-933, ISBN 978-0123341600, San Diego, USA.

Geyer, H.; Freitag, D. \& Korte, F. (1984). Polychlorinated biphenyls (PCBs) in the marine environment, particularly in the Mediterranean. Ecotoxicology and Environmental Safety, Vol.8, pp. 129-151, ISSN 0147-6513.

Gilden, RC.; Huffling, K. \& Sattler, B. (2010). Pesticides and health risks. Journal of Obstetric, Gynecologic, and Neonatal Nursing (JOGNN), Vol.39, pp. 103-110, ISSN 0884-2175.

Gold, LS.; Slone, TH. \& Ames, BN. (2001). Pesticide Residues in Food and Cancer Risk: a Critical Analysis, In: Handbook of Pesticide Toxicology, Second Edition, R. Krieger (Ed.), 799-843, ISBN 978-0124262607, San Diego, USA.

Grindon, C. \& Combes, R. (2006). Introduction to the EU REACH legislation. ATLA Alternatives to Laboratory Animals, Vol.34, Suppl.1, pp. 5-10, ISSN 02611929.

Grindon, C.; Combes, R.; Cronin, MT.; Roberts, DW. \& Garrod, J. (2006). A review of the status of alternative approaches to animal testing and the development of integrated testing strategies for assessing the toxicity of chemicals under REACH a summary of a DEFRA-funded project conducted by Liverpool John Moores 
University and FRAME. ATLA Alternatives to Laboratory Animals, Vol.34, Suppl.1, pp. 149-158, ISSN 02611929.

Hassall, KA. (1990). The Biochemistry and Use of Pesticides. Structure, Metabolism, Mode of Action and Use in Crop Protection. MacMillan, ISBN 978-0895739766, NewYork, USA.

Karaouzas, I.; Cotou, E.; Albanis, TA.; Kamarianos, A.; Skoulikidis, NT. \& Giannakou, U. (2010). Bioassays and biochemical biomarkers for assessing olive mill and citrus processing wastewater toxicity. Environmental Toxicology, n/a, ISSN 1520-4081.

Kennedy, SW. (1991). The Mechanism of Organophosphate Inhibition of Cholinesterase Proposal for a New Approach to Measuring Inhibition, In: Cholinesterase-inhibiting Insecticides: Their Impact on Wildlife and the Environmental. Chemical in Agriculture, P. Mineau (Ed.), Vol.2, 74-87, ISBN 9780444887078, Amsterdam, Holland.

Kuhr, RJ. \& Dorough, HW. (1976). Carbamate Insecticides: Chemistry, Biochemistry, and Toxicology, In: Handbook of Pesticide Toxicology, JH. Wayland, RL. Edward, (Eds), 4170, ISBN 9780878190522, Cleveland, (USA).

Loomis, WF. (1975). Dictyostelium discoideum: A Developmental System, Academic Press, ISBN 9780124561502, New York, USA.

Louekari, K.; Sihvonen, K.; Kuittinen, M. \& Sømnes, V. (2006). In vitro tests within the REACH information strategies. ATLA Alternatives to Laboratory Animals, Vol.34, No.4, pp. 377-386, ISSN 02611929.

Massoulié, J.; Pezzementi, L.; Bon, S.; Krejci, E. \& Vallette FM. (1993). Molecular and cellular biology of cholinesterases. Progress in Neurobiology, Vol.41, No.1, pp. 31-91, ISSN 0555-4047.

McCauley, DJ.; DeGraeve, GM. \& Linton, TK. (2000). Sediment quality guidelines and assessment : overview and research needs. Environmental Science $\mathcal{E}$ Policy, Vol.3, pp. 133-144, ISSN 1462-9011.

Mendel, B. \& Rudney, H. (1943). Studies on cholinesterase: 1. Cholinesterase and pseudocholinesterase. The Biochemical Journal, Vol.37, No.1, pp. 59-63, ISSN 0264-6021.

Miyoshi, N.; Kawano, T.; Tanaka, M.; Kadono, T.; Kosaka, T.; Kunimoto, M.; Takahashi, T. \& Hosoya, H. (2003). Use of Paramecium species in bioassays for environmental risk management: determination of IC50 values for water pollutants. Asian Journal of Health Science. Vol.46, No.6, pp. 429-435, ISSN 1671-5927.

Monserrat, JM.; Martínez, PE.; Geracitano, LA.; Amado, LL.; Martins, CM.; Pinho, GL.; Chaves, IS.; Ferreira-Cravo, M.; Ventura-Lima, J. \& Bianchini, A. (2007). Pollution biomarkers in estuarine animals: critical review and new perspectives. Comparative Biochemistry and Physiology - Part C: Toxicology \& Pharmacology, Vol.146, pp. 221-234, ISSN 1532-0456.

Nachmansohn, D. \& Machado, AL. (1943). The formation of acetylcholine. A new enzyme choline acetylase. Journal of Neurophysiology, Vol.6, pp. 397-403, ISSN 0022-3077.

Orlans, BF. (1993). In the Name of Science, In: Responsible Animal Experimentation, Oxford University Press, 312, ISBN 978-0195108712, New York, USA.

Pal, A.; Gin, KY.; Lin, AY. \& Reinhard, M. (2010). Impacts of emerging organic contaminants on freshwater resources: review of recent occurrences, sources, fate and effects. Science of the Total Environment, Vol.408, pp. 6062-6069, ISSN 0048-9697.

Persoone, G. \& Dive, D. (1978). Toxicity tests on ciliates: a short review. Ecotoxicology and Environmental Safety, Vol.2, No.2, pp. 105-14, ISSN 0147-6513. 
Ramoino, P.; Milanese, M.; Candiani, S.; Diaspro, A.; Fato, M.; Usai, C. \& Bonanno, G. (2010). Gamma-amino butyric acid (GABA) release in the ciliated protozoon Paramecium occurs by neuronal-like exocytosis. The Journal of Experimental Biology, Vol.213, pp. 1251-1258, ISSN 0022-0949.

Rattner, B. \& Fairbrother, A. (1991). The Mechanism of Organophosphate Inhibition of Cholinesterase - Proposal for a New Approach to Measuring Inhibition, In: Cholinesterase-inhibiting Insecticides: Their Impact on Wildlife and the Environmental. Chemical in Agriculture, P. Mineau (Ed.), Vol.2, 89-101, ISBN 9780444887078, Amsterdam, Holland.

Ricci, N. (1995). Protozoa; Bioindicators of Environmental Monitoring and Pollution Control, In: Pollution and Biomonitoring, Tata Mc Graw-Hill, 240-269, New Delhi, India.

Ruano, F.; Campos, M.; Sánchez-Raya, AJ. \& Peña, A. (2010). Olive trees protected from the olive bark beetle, Phloeotribus scarabaeoides (Bernard 1788) (Coleoptera, Curculionidae, Scolytinae) with a pyrethroid insecticide: Effect on the insect community of the olive grove. Chemosphere, Vol.80, pp. 35-40, ISSN 0045-6535.

Russel, WMS. \& Burch RL. (1959). The Principles of Humane Experimental Tecnique. Metheuen and Co Ltd, ISBN 0-900767-78-2, London, England.

Sandulli, R. (2004). Il ruolo degli indicatori biologici nella valutazione dello stato dell'ambiente marino. Biologia Marina Mediterranea, Vol.11, pp. 185-192, ISSN 11234245.

Sauvant, MP.; Pepin, D. \& Piccinni, E. (1999). Tetrahymena pyriformis: a tool for toxicological studies. A review. Chemosphere, Vol.38, No.7, pp. 1631-1669, ISSN 0045-6535.

Schechtman, LM. (2002). Implementation of the 3Rs (refinement, reduction, and replacement): validation and regulatory acceptance considerations for alternative toxicological test methods. ILAR Journal, Vol.43, pp. S85-S94, ISSN 1084-2020.

Stedman, E.; Stedman, E. \& Easson, LH. (1932). Choline-esterase. An enzyme present in the blood-serum of the horse. The Biochemical journal, Vol.26, No.6, pp. 2056-66, ISSN 0264-6021.

Stokes, WS. \& Hill, RN. (2002). The Role of ICCVAM in Evaluating New and Alternative Test Methods. Lab Animal, Vol.31, No.7, pp. 26-32, ISSN 0093-7355.

Stroud, RM.; McCarthy, MP. \& Shuster, M. (1990). Nicotinic acetylcholine receptor superfamily of ligand-gated ion channels. Biochemistry, Vol.29, No.50, pp. 1100911023, ISSN 0006-2960.

Talesa, V.; Contenti, S.; Mangiabene, C.; Pascolini, R.; Rosi, G. \& Principato GB. (1990). Propionylcholinesterase from Murex brandaris: Comparison with other invertebrate cholinesterases. Comparative Biochemistry and Physiology Part C: Toxicology $\mathcal{E}$ Pharmacology, Vol.96, No.1, pp. 39-43, ISSN 1532-0456.

The Worldwatch Institute. (2006). Vital Signs 2006-2007: the trends that are shaping our future. WW. Norton, (Ed), ISBN 0393328724, New York, (USA).

Trielli, F.; Amaroli, A.; Sifredi, F.; Marchi, B.; Falugi, C. \& Delmonte Corrado, MU. (2007). Effects of xenobiotic compounds on the cell activities of Euplotes crassus, a singlecell eukaryotic test organism for the study of the pollution of marine sediments. Aquatic Toxicology, Vol.83, No.4, pp. 272-283, ISSN 0166-445X.

Turkewitz, AP.; Orias, E. \& Kapler, G. (2002). Functional genomics: the coming of age for Tetrahymena thermophila. Trends in Genetics, Vol.18, pp. 35-40, ISSN 0168-9525. 
Van Maele-Fabry, G.; Lantin, AC.; Hoet, P. \& Lison, D. (2011). Residential exposure to pesticides and childhood leukaemia: a systematic review and meta-analysis. Environment International, Vol.37, pp. 280-291, ISSN 0160-4120.

Weichenthal, S.; Moase, C. \& Chan, P. (2010). A review of pesticide exposure and cancer incidence in the Agricultural Health Study cohort. Environmental Health Perspectives, Vol.118, pp. 1117-1125, ISSN 0091-6765.

Weisskopf, MG.; Knekt, P.; O'Reilly, EJ.; Lyytinen, J.; Reunanen, A.; Laden, F.; Altshul, L. \& Ascherio, A. (2010). Persistent organochlorine pesticides in serum and risk of Parkinson disease. Neurology, Vol.74, pp. 1055-1061, ISSN 0028-3878.

Williams, RS.; Boecheler, K.; Grod, R.; Gräf, R.; Müller-Taubenberger, A.; Li, Z.; Isberg, RR.; Wessels, D.; Soll, DR.; Alexander, H. \& Alexander, S. (2006). Towards a molecular understanding of human diseases using Dictyostelium discoideum, Trends in Molecular Medicine, Vol.12, pp. 415-424, ISSN 1471-4914. 


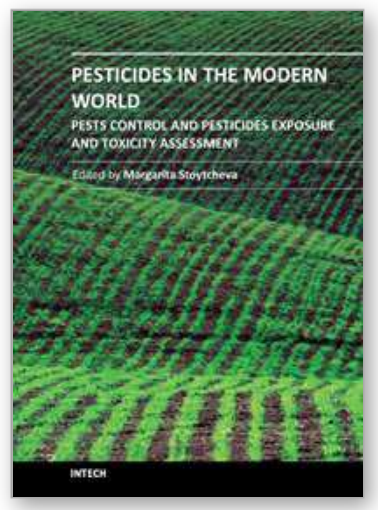

\section{Pesticides in the Modern World - Pests Control and Pesticides Exposure and Toxicity Assessment}

Edited by Dr. Margarita Stoytcheva

ISBN 978-953-307-457-3

Hard cover, 614 pages

Publisher InTech

Published online 30, September, 2011

Published in print edition September, 2011

The present book is a collection of selected original research articles and reviews providing adequate and upto-date information related to pesticides control, assessment, and toxicity. The first section covers a large spectrum of issues associated with the ecological, molecular, and biotechnological approaches to the understanding of the biological control, the mechanism of the biocontrol agents action, and the related effects. Second section provides recent information on biomarkers currently used to evaluate pesticide exposure, effects, and genetic susceptibility of a number of organisms. Some antioxidant enzymes and vitamins as biochemical markers for pesticide toxicity are examined. The inhibition of the cholinesterases as a specific biomarker for organophosphate and carbamate pesticides is commented, too. The third book section addresses to a variety of pesticides toxic effects and related issues including: the molecular mechanisms involved in pesticides-induced toxicity, fish histopathological, physiological, and DNA changes provoked by pesticides exposure, anticoagulant rodenticides mode of action, the potential of the cholinesterase inhibiting organophosphorus and carbamate pesticides, the effects of pesticides on bumblebee, spiders and scorpions, the metabolic fate of the pesticide-derived aromatic amines, etc.

\section{How to reference}

In order to correctly reference this scholarly work, feel free to copy and paste the following:

Andrea Amaroli (2011). The Effects of Pesticides on Dictyostelium Cholinesterase, from Basic to Applied Research, Pesticides in the Modern World - Pests Control and Pesticides Exposure and Toxicity Assessment, Dr. Margarita Stoytcheva (Ed.), ISBN: 978-953-307-457-3, InTech, Available from:

http://www.intechopen.com/books/pesticides-in-the-modern-world-pests-control-and-pesticides-exposure-andtoxicity-assessment/the-effects-of-pesticides-on-dictyostelium-cholinesterase-from-basic-to-applied-research

\section{INTECH}

open science | open minds

\author{
InTech Europe \\ University Campus STeP Ri \\ Slavka Krautzeka 83/A \\ 51000 Rijeka, Croatia \\ Phone: +385 (51) 770447 \\ Fax: +385 (51) 686166 \\ www.intechopen.com
}

\author{
InTech China \\ Unit 405, Office Block, Hotel Equatorial Shanghai \\ No.65, Yan An Road (West), Shanghai, 200040, China \\ 中国上海市延安西路65号上海国际贵都大饭店办公楼 405 单元 \\ Phone: +86-21-62489820 \\ Fax: +86-21-62489821
}


(C) 2011 The Author(s). Licensee IntechOpen. This chapter is distributed under the terms of the Creative Commons Attribution-NonCommercialShareAlike-3.0 License, which permits use, distribution and reproduction for non-commercial purposes, provided the original is properly cited and derivative works building on this content are distributed under the same license. 